\title{
Prescriptivism, linguicism and pedagogical coercion in primary school UK curriculum policy
}

\begin{tabular}{|r|l|}
\hline Journal: & English Teaching: Practice and Critique \\
\hline Manuscript ID & ETPC-05-2019-0063.R2 \\
\hline Manuscript Type: & Research Article \\
\hline Keywords: & $\begin{array}{l}\text { linguicism, language tests, pedagogical coercion, educational language } \\
\text { policy, curriculum policy }\end{array}$ \\
\hline
\end{tabular}

SCHOLARONE $^{\mathrm{m}}$
Manuscripts $^{\text {Manusion }}$ 


\title{
Prescriptivism, linguicism and pedagogical coercion in primary school UK curriculum policy
}

\author{
1. Introduction \\ 'Othered' languages and language varieties have long been marginalised in UK schools (e.g. \\ Cameron, 1995; Cheshire, 1982; Crowley 2003). By 'othered', I refer to languages other than English, \\ and varieties other than Standardised English (SE), which have been the victims of stigmatisation and \\ linguicism at the hands of policy makers and curriculum writers. Linguicism, akin to other -isms such \\ as racism, ageism and sexism, is an important concept for this paper, defined as:
}

ideologies, structures and practices which are used to legitimate, effectuate and reproduce an unequal division of power and resources (both material and non-material) between groups which are defined on the basis of language. (Skutnabb-Kangas, 1988: 13)

In this paper, I argue that current UK primary school government education policy embodies, legitimises and encourages linguicism in a number of ways, but particularly in relation to the way that $\mathrm{SE}$ and intra-language variation is conceptualised. For instance, students are under compulsory requirements to learn, use and appreciate $\mathrm{SE}$ without any requirement to learn about linguistic variation or to engage critically with why SE is typically seen as powerful and culturally 'valuable' (Bourdieu, 1991). This espousal of SE is perhaps most notable in the form of national grammar tests for 10-11-year olds, part of which require students to identify 'errors' in non-standardised English, and then intervene by 'correcting' these into SE. The tests assess decontextualized linguistic knowledge, where language is reduced to a set of positivist 'right' or 'wrong' answers and conceptualised as a system of 'rules and regulations' (Cushing, 2018, 2019), and are taken within a culture of high-stakes performativity (Ball 2003), where teachers' pedagogies are regulated and controlled by authoritative policies and narrow curricula. Indeed, the very idea of 'standard' and 'nonstandard' language varieties is in itself problematic, used to reinforce hegemonic ideologies and categories of 'inclusion' and 'exclusion' (Milroy, 1999; Shohamy, 2006: 22-44). I return to a discussion of these tests, and the wider curriculum they sit within, in the following section. The research questions used to steer the study are as follows:

1. What are primary school teachers' perceptions of the way that language is conceptualised within current policy and assessments?

2. How much power do current language policies and assessments have in terms of affecting teachers' pedagogical decisions?

At the heart of this paper is the idea that these kinds of linguicist and prescriptive curriculum policies and high-stakes tests can coerce teachers into pedagogies that they do not necessarily believe in. The aims of this research then, are to trace instances of what Bonacina-Pugh (2012) calls 'practiced language policy', in examining teachers' perceptions of how policy comes to affect their teaching in particularly regulatory ways. The paper offers a critical take on literacy education in UK policy, revealing some of the ways in which tests and curricula can distort, regulate and narrow pedagogies. Whilst my focus is on the school as a community setting, I follow Corson's (1999) argument that schools can reproduce forms of language stigmatisation and repression found in broader societal contexts, and that school language policies are often based on policy making at community and national level (see also May, 2012: 175-176).

My starting point lies in the assumption that curricula and policy are powerful political and ideological tools, which function as 'mechanisms for organizing, managing and manipulating language behaviors as [they] consist of decisions made about languages and their uses in society' (Shohamy, 2006: 45). This conceptualization of language policy is important in that it immediately connects linguistic issues to broader sociopolitical concerns such as education (e.g. Pennycook, 2001: 10 ), and so analysis requires unpicking discourse about language across different policy 'levels' or 'layers' (e.g. Barakos and Unger, 2016; Ricento and Hornberger, 1996; Johnson, 2018). These three 
demonstrate an understanding of and take responsibility for promoting high standards of literacy, articulacy and the correct use of standard English, whatever the teacher's specialist subject. (DfE, 2013b: 11, my emphasis)

This evaluative framing of language as 'correct', and the equating of 'Standard English' to 'high standards' is perhaps most explicitly available in the Grammar, Punctuation and Spelling (GPS) tests, compulsory assessments which were introduced by government to primary schools in 2013 . The tests were introduced following recommendations in the Bew Report (DfE, 2011) that 'technical' parts of language such as grammar, spelling and punctuation could and should be tested, on the grounds that there are "clear "right" and "wrong" answers' (ibid., 60). Around the time of curriculum reform, the government used rhetoric around 'falling standards' and 'low literacy rates' (e.g. Gove, 2014), whipping up a sense of 'moral panic' and crafting a 'linguistic emergency' (Cameron, 1995: 89) in order to legitimize the introduction of these tests and garner support for education policy changes. The media, too, play a role in promoting prescriptivism in schools, giving a platform to language 'policing' in the classroom and highlighting punitive policies without any sense of criticism or sociolinguistic viewpoints (see Cushing, in press for a detailed discussion). Whilst prescriptivism in UK education policy is nothing new (see Carter, 1996; Clark, 2001; Hudson, 2016), I argue that the current curriculum is particularly reflective of conservative, reductive and misguided views about language.

A critical perspective sees language tests as mechanisms and 'rituals' used by those in authority to control and regulate language use in determining the prestige and status of languages, perpetuating language 'correctness' and suppressing linguistic diversity (Shohamy, 2001; see also Lingard 2012). The GPS tests have high-stakes in terms of performativity, used to measure children's progress, to compare the performance of schools within 'league tables', and ultimately, hold teachers to account for their work (e.g. Ball, 2003; Dearden and Vignoles, 2011). Furthermore, they can be highly damaging to the academic achievement and linguistic identities of minority students (see Piller, 2016: 113-120), especially if they are monolingual and/or monodialectal, which the GPS tests are. In these positivist tests, students are required to identify elements of grammar in decontextualized, isolated sentences, and 'correct' examples of language which are deemed to be 'incorrect'. 'Correct' 
forms are all written in SE, using synthesized examples engineered for testing purposes rather than reflecting actual language use. For example, a question from the 2018 paper is as follows:

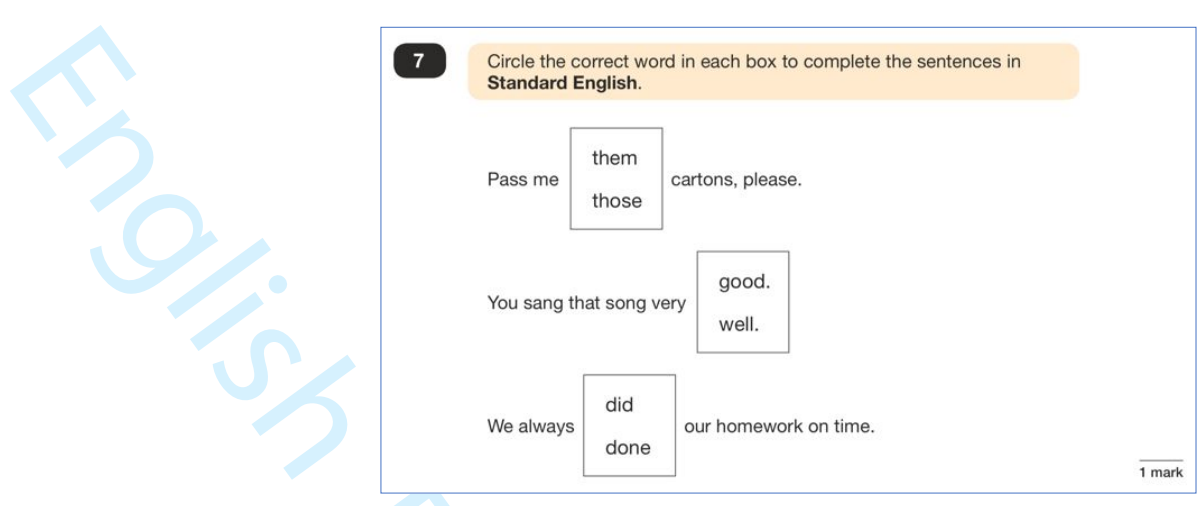

Figure 1: Standard English and 'correctness' in the GPS tests

The ideology behind this question is that there is a 'correct' way of using language, and that way is SE. As in Figure 1, many questions contrast SE constructions with non-standardized constructions, reinforcing imagined, delineated 'boundaries' between language varieties, and prompting children to acknowledge SE as the 'right' way of using language. This of course, is despite the fact that grammatical constructions in non-standard varieties of English are legitimate forms of the language and an important index of social identity, especially in school and community contexts (e.g. Levey 2012; Snell, 2018). For instance, the use of 'them' as a determiner in the first question in Figure 1 is a long-established grammatical characteristic of many UK varieties (e.g. Cheshire \& Edwards 1991; see also Cushing, 2018 for a criticism of auxiliary verb 'was/were' variation and error correction in the tests). The tests and the curriculum are underpinned by a prescriptive and linguicist ideology, with the use of categorical and evaluative adjectives such as 'right', 'wrong', 'correct' and 'incorrect', foregrounding the idea that there are ways of using language which children should conform to. Despite there being no evidence to suggest that clause-level, decontextualised, error-correction grammar pedagogies will have any positive effect on students' literacy abilities (see Hudson, 2001; Myhill \& Watson, 2014), the Minister of State for School Standards, Nick Gibb ${ }^{1}$, insisted on the tests doing just that:

One fundamental outcome of a good education system must be that all children, not just the offspring of the wealthy and privileged, are able to write fluent, cogent and grammatically correct English [...] All children, irrespective of birth or background, should be able to write prose where verbs agree with subjects, commas separate independent clauses, and pronouns agree in number with the nouns to which they refer. (Gibb, 2016)

Following this critical discussion of macro-level language education policies in the UK and the sociopolitical context in which they operate, I next describe the methods taken to acquire and understand views and perceptions from teachers.

\section{Methods}

The aims of this research are to trace instances of 'practiced language policy' (Bonacina-Pugh, 2012), with a particular focus on how teachers may perceive, defend and resist instances of macro-level prescriptivism and linguicism. In order to explore these aims and answer the research questions, I designed and conducted semi-structured interviews with practicing primary school teachers $(n=22)$. These teachers were recruited through a call for participation placed on social media and teachers' forums, and so the sampling pool was limited to those who were active online. None of the

\footnotetext{
${ }^{1}$ Nick Gibb is the Minister of State for School Standards, and ultimately responsible for the actions of the Department for Education in regard to the GPS tests. He has no experience or academic expertise in schools and wider education, having become a politician after working in the financial sector.
} 
participants had received any formal training in linguistics as part of their under/postgraduate studies, as is the case with the majority of teachers in the UK (see Giovanelli, 2016). One interview with each participant took place (over telephone or video call), lasting between 15-45 minutes, and these were audio recorded, and then transcribed. Questions were geared around teachers' views of language as presented within current curriculum policy and how this impacted upon the kind of pedagogical decisions they made in the classroom. A selection of broad questions (many of which prompted further questions) is as follows:

- How do you feel about the emphasis on standard English within current curriculum policy?

- How do you feel about words such as 'correct' and 'incorrect' used to describe language, especially in educational contexts?

- What kind of pedagogical methods do you use in teaching about standard English in your classroom, and what are the reasons for these?

The interviews were useful in providing an 'insider' perspective on educational policy and the 'lived experience' (e.g. Garvis, 2015) of the teachers in delivering the curriculum. My choices in designing the interview questions were underpinned by the approaches to interviewing advocated by Brinkmann and Kvale (2015), where interviews are construed as a form of knowledge-producing social interaction (ibid., 20-21). All participant names were anonymised.

I thematically coded and indexed all transcriptions using NVivo software. The purpose of coding was to provide a way of organising the data, serving a useful practical endeavour in spotting patterns across the datasets, and a way of ensuring analytical validity in ensuring that all data was considered. In accordance with Elliot's (2018) call for a contextually-sensitive, pragmatic, 'decisionmaking' approach to coding, I used a blend of deductive and inductive methods, starting with some broad a priori themes about attitudes to language, curriculum policy and grammar teaching, and allowing for the creation of new themes as I coded. These a priori themes were driven by the research aims, namely around conceptualizations of language within policy and instances of linguicism in practice, which I focus on in sections 4.1 and 4.2. Some of these new codes included the way that participants talked about standard English as a proxy for other sets of behaviours, societal values, employment and economy. This is taken up in section 4.3. Although 22 teachers were interviewed, data in the sections that follow is taken from 10 participants. This data was selected because it provided a good representation of the most prominent themes, included a range of teacher attitudes about language, and a variety of number of years teaching experience. The details of these 10 teachers are shown in Table 1:

\begin{tabular}{|c|c|}
\hline Name & Number of years teaching \\
\hline Sara & 14 \\
\hline Miles & 11 \\
\hline Daisy & 10 \\
\hline Alex & 7 \\
\hline Beth & 9 \\
\hline Ola & 3 \\
\hline Theo & 2 \\
\hline Hina & 5 \\
\hline Ella & 5 \\
\hline Rachel & 15 \\
\hline
\end{tabular}

\section{Table 1: Participant details from which data is drawn from}

\section{Analysis and discussion}

The following sections are organized around the major themes which were found in the dataset, of which there are three: macro-level policy as pedagogical coercion; Standard English and linguicism, and Standard English as a proxy for social factors. I draw on data coded under these themes to 
illustrate how teachers interpreted, enacted and resisted curriculum language policy, drawing links between interview discourse and macro-level policy as discussed in the preceding sections.

\subsection{Macro-level policy as pedagogical coercion}

One of the major themes present in the data was the idea that macro-level policy was authoritative and controlling, in terms of what it made teachers think and feel about language, and the kind of language pedagogies that they engaged with as a result. Framed here as 'pedagogical coercion', this reveals the 'power' of the tests in the way that they regulate classroom decisions (see Shohamy 2001). As an illustration, the following turn is from Sara, a teacher of 14 years with a background in English literature. This occurred during a discussion around how the current curriculum and the GPS tests emphasised decontextualized grammatical knowledge over using language in applied or critical ways:

Sara:

what I find with this curriculum (.) especially compared to previous ones I think (.) is that it's all about just grammar subject knowledge (.) in terms of word classes phrases and those kinds of things (.) just endless labelling things and circling things (.) it's how I remember being taught grammar forty years ago (.) to me it's well (1) that kind of work isn't really about language at all it's just about categorising things for the sake of it (.) but I'm trapped in this way of doing endless rules and saying yes that's right or that's wrong you know (.) and I hate that because (.) well the reason we do that is because of the tests and I think it was quite different before that

Sara's turn shows that she is engaging critically with the curriculum yet feels disempowered in how to resist it in practical terms, using metaphors of entrapment to describe her feelings of pedagogical coercion. She compares the current NC as markedly different to previous versions, especially in the emphasis and amount of grammar as a discrete body of knowledge to be learnt by students, even comparing it to the way that she was taught grammar 'forty years ago', during which grammar pedagogies were characterised by decontextualized drills (see Hudson, 2016). This then, has resonances of the 'traditional' teaching ideologies and pedagogies which underpinned the very design of the macro-level curriculum, and the kinds of beliefs about language and education which typify c/Conservative education policies. This macro-level policy, for Sara, places a restrictive pedagogical grip on the kinds of policy decisions she is able to make in her own classroom ('trapped in this way of doing endless rules'). Her idea of feeling 'trapped' is akin to Clark's (2001: 148) 'strait-jacket' metaphor, used to frame the ways that teachers can feel an increasing loss of professional autonomy as a result of reductive changes to language education policies.

Although Sara does not explicitly describe what she believes to be valuable language work, she positions herself as being critical of the way that language is conceptualised within current policy. Her declaration that the curriculum and the tests '[are not] really about language at all', that they are about 'endless rules' and being 'right or [...] wrong' suggests that she values a descriptive approach to language study yet is forced into thinking about language and language pedagogies in prescriptive ways. She cites the reason for this as being 'the tests', which, as demonstrated in section 2, frame language in binary 'correct' or 'incorrect' ways. Other interview participants also bemoaned the prescriptive grammar of curriculum policy and the tests, including the language of the test questions and example sentences:

Miles: $\quad$ I suppose the tests talk about things being right or wrong and correct or incorrect (.) and I'm not sure I think that's useful for students (.) like I know that's not a sensible way to think about language so why are we forced into teaching it like that? imagine what else I could be doing with language

And

Daisy: the sentences on the tests I cannot bear (.) they are so false and just invented for those tests and um (.) yeah (.) so fake and just so far away from how my pupils actually use language (.) there are just so many other interesting things 
we could be doing with language yet my classroom has just become this weird place where we study invented sentences and then underline bits of them (.) and then pretend this is useful in their writing or whatever

Alex:

they've definitely changed the way I teach grammar (.) you know much more focus on little bits of rules and underlining bits often just for the sake of it I think (.) I find myself saying stuff about grammar that I don't really believe in just because those tests take up so much time you know

Again, teachers' criticisms of macro-level policy are set against feelings of pedagogical restrictions, constraints, a growing sense of deprofessionalization and a critical sense of 'not believing in' the curriculum. These criticisms are here directed towards the idea that the way language is conceptualized within policy and assessments is false, reductive and pedagogically empty. Miles and Daisy both imagine alternative classrooms and pedagogies ('imagine what I could be doing with language'; 'there are just so many other interesting things we could be doing'), foregrounding their dismay at the curriculum and its' apparent control over their own classroom decisions.

Taken together, the extracts in this section point towards the fact that teachers operate within a punitive and hierarchical language policy context, which can strip them of their own autonomy in terms of classroom decisions and come to 'standardize' their own language policies and pedagogies. Top-down curriculum policy conceptualizes language as a standardized, finite system, which serves as a mechanism to regulate language policies and pedagogies at 'lower' levels, despite policy arbiters at these levels expressing criticism of this. As Shohamy suggests about standardization in language policies and their effects of 'imposition':

Standardization means that languages need to be used in certain ways, often in sharp contrast to how they are actually used by people [...]. It is therefore considered a form of linguistic engineering and imposition on personal freedom, as it strives to force people to use languages in uniform ways [...]. It is a clear case of top-down imposition by those in authority [...] and thus places major limitations on the freedom of expression and speech. (Shohamy, 2006: 65)

The following section builds on the concept of standardization by considering teachers' views on the foregrounding of SE within macro-level policy.

\subsection{Standard English and linguicism}

A second major theme across the dataset was related to teachers' perceptions of SE, the function it played, and how this might operate as an instance of linguicism. Discussion of this issue was largely prompted by questions around how teachers 'managed' non-standard varieties as part of their own policies, given that they had a professional obligation to teach SE and to teach the content of the GPS tests.

For many participants, the place of non-standard English had been marginalized as a result of macro-level policy, with few, if any, opportunities for engaging in work of a more critical, sociolinguistic nature, where issues such as perceptions towards language varieties might be explored (see for example, Godley and Reaser, 2018). Daisy's turn in the previous section touched on some of these issues, in her idea that 'the sentences on the tests [...] are so false and just invented for those tests $[\ldots]$ so fake and just so far away from how my pupils actually use language'. Another participant, Beth, said that she felt 'under pressure to talk about the need to use standard English', and that this 'felt different' to previous versions of the curriculum and 'how she was taught about the need to respect language variation as part of [her] teacher training'. As a further example, Ola's turn below highlights how she felt she had to label her students' local dialect as 'wrong' because of the demands placed on her by the curriculum and by the tests:

Ola: the way I feel about that is (1) well (.) the test questions and all of the stuff on the curriculum is about using language formally (.) I guess that is standard 
English (.) and it feels weird in the classroom using that and saying it's right and correct (.) it's so false

Int: can you give an example of that? from the classroom?

Ola: well the test questions all use examples only in standard English which sounds quite different to how my class use language [...] I mean for example the other day we were doing some sample questions and I had to tell the class the way they were using language was wrong because (.) well they wouldn't have got a mark for it in the test using language the way they do

Ola here is coerced into an act of linguicism, despite explicitly knowing that this is a problematic way of conceptualizing language. She has difficulty accepting the kind of evaluative, positivist language of the curriculum and of the tests, instead choosing to problematize the notion of language as 'right' or wrong', and in doing so, positions herself as a teacher who wishes to resist the curriculum yet feels powerless to do so in practical terms. The linguistic reference point by which her pupils are measured against feels, to her, 'weird' and 'false', as she is forced into dealing linguistic 'sanctions' (Tollefson, 1991: 14) which constrain her pupils' language use and clash with her own policies about language. Later in the interview, Ola talked about her 'love' of language variation and regional dialects (as did many other participants), and so the language policy that she was forced into adopting as a result of macro-level policy was clearly incongruent with what she truly believed in.

Not all participants were critical of the curriculum language policy, with many instead choosing to position themselves as language 'police' whose role was to further regulate language use in the classroom. For example:

Theo: $\quad$ actually I think as teachers we have responsibility for making sure students are speaking correctly and using the correct grammar (.) I like to think of myself as the grammar police and I'll quite happily stop the class make a siren noise and point out an error in somebody's writing or whatever (.) I know it might sound a bit childish but my children in my class need it I think Int: $\quad$ and do you ever use that phrase (.) grammar police? with your class? Theo: $\quad$ god yeah (.) I have a poster behind my desk that says I'm watching them all (.) sometimes I say the classroom is a crime scene [laughter]

Theo positions himself as a powerful language policy arbiter who is both capable and ready to engage in linguicism, seemingly without considering the sensitivities of his students and their own linguistic identities. He speaks for students, adopting 'responsibility' for the way that they use language. Instances like the ones he describes depict his classroom is one of surveillance ('I have a poster behind my desk that says I'm watching them all') and humiliation ('I'll quite happily stop the class [...] and point out an error'). His use of a 'police' metaphor ('grammar police', 'siren noise', 'crime scene') might be seen to be in jest and he attempts to mitigate his actions by acknowledging that they 'might sound a bit childish', but a critical take on this would describe such policies as punitive, discriminatory and suppressive (see Cushing, in press for a further discussion of language policing in schools). Theo provides no reason for his 'policing' apart from the idea that 'teachers have responsibility for making sure students are speaking correctly', forging a textual and ideological contact point with the Teachers' Standards policy, first discussed in section 2 (DfE 2013b). As an English-speaking, white, adult male, Theo is a prototypical member of the most powerful social group in the world, and in engaging in language policing and linguicism serves to entrench the authority of this group, fulfilling a role as a 'powerful participant' who holds both instrumental and institutional power (Fairclough, 2014), and placing him as a consensual 'vehicle' for the macro-level language policies designed by government. Theo's attitudes to language and curriculum then, can be textually traced as part of his practiced language policy. As Corson argues, language attitudes and policies are intimately linked:

Attitudes to nonstandard speech held by teachers are important variables that will influence the design of a language policy. There is no doubt that nonstandard varieties of language are just as regular, flexible, and logical as the standard form, even though the standard variety is 
more highly valued in schools, on the grounds that it is the standard. Yet negative attitudes to students' language held by various groups of people, including teachers, continue to influence their attitudes to the students themselves in ways that have little to do with the students' intellectual potential. (Corson 1999: 42)

Later in the interview, Theo talked positively about recent changes the curriculum, drawing further connections between his practiced language policy and the macro-level policy of the current curriculum. He suggested that the requirement for students to be tested on their knowledge of SE was a 'good step forward' because students needed this to access jobs and enjoy educational achievements. In a similar way, Hina was adamant that her students 'always made errors in their speech' and that the emphasis on standard English had 'been a good thing in teaching them about the need to speak properly [...] for jobs and work and things'. This indexing and correlating of SE to other socio-economic factors is taken up in the following section.

\subsection{Standard English as a proxy}

Although participants were often seen to be critical of the way that SE is promoted in policy, there was little critical engagement with some of the socio-historical reasons for why SE carries prestige in the majority of social contexts. Although language clearly 'intersects' with social factors such as ethnicity and class (e.g. Piller, 2016), it is also often conceptualized as a proxy for things such as economic prosperity and educational opportunities, as Theo's turn above touched upon. Language as a proxy for other factors has long been discussed in critical sociolinguistics, especially in broad educational discourse (e.g. Cameron, 1995: 78-115) but has received limited attention in regard to this being a form of language policy and how it relates to macro-level government and curriculum discourses. Participants in the current study used language as a proxy for a host of other social factors such as economic prosperity, employment chances, academic achievement, and the maintenance of standards. For instance:

Ella: $\quad$ I know some people don't like the new curriculum and the grammar tests but actually I think it's a good thing (.) because ultimately students need to be able to use language properly in order to get jobs and do well in life and you know (.) we're here to show them how to do that

Ella's defense of the curriculum and language policies is geared around language as a proxy for educational and employment opportunities. I suggest that instances such as these are benevolent guises of teachers 'giving' children access to things such as jobs and economic success, yet in reality, often serve as acts of linguicism in further entrenching the perceived links between language, education and employment, and deepen social injustices. This link can be found in macro-level government discourse about literacy, community and employability, such as in Gove (2014) who draws direct connections between 'illiteracy' and 'joblessness', and in Gibb (2018) who champions the tests on the grounds that they have a positive effect on literacy, despite there being no research to suggest that decontextualized, error-correction language pedagogies will do so (see Myhill and Watson 2014). What the policies do appear to point to then, is the perception that SE carries in terms of intellectual ability, and studies have suggested that teachers do indeed tend to evaluate nonstandard forms in negative terms, despite student ability (e.g. Godley et al., 2007). A further example also drew a strong connection between language and economic success:

Int: $\quad$ so can I ask what you think happens if your students have a good knowledge of standard English?

Rachel: $\quad$ well I guess ultimately they'll get much better jobs (.) later on

Int: $\quad$ why is that do you think?

Rachel: because if they can use (.) if they can use the proper standard language then it looks good on them (.) so better places at university and then jobs (.) and then more money (.) it's a shame I suppose to think of it like in terms of money but that's the truth isn't it? 
Rachel acknowledges that it is a 'shame' to think of language as a proxy for economy, but ultimately, her policy views do not challenge some of these normative assumptions about language education policy. Despite the fact that her students are only 10-years-old, they are still talked about in relation to university places and jobs. Language here then, specifically SE, comes to be conceptualized as a commodity (e.g. Duchêne and Heller, 2012; Holborow, 2015; Park and Wee, 2012), amidst a pressure of neoliberalism and aligned with business, capital and finance. SE is the variety of English which holds the highest value on the linguistic 'market' (Bourdieu, 1991), the 'key' to accessing economic success and social power (Park and Wee, 2012: 186), and the school itself as a site of entrepreneurial activity and training for the corporate world (Pennycook, 2001).

\section{Conclusions, implications and alternative approaches}

This paper has problematized the way that language is conceptualized within UK education policy and assessments, especially in terms of linguicism and degrees of pedagogical coercion. Using a critical approach to language policy and language ideologies, I argued that there are explicit traces of linguicism as found across macro and micro policy levels: from government produced policies and tests, through to individual teachers' classroom pedagogies. Instances of linguicism in the dataset were often seen to be a partial result of particularly conservative changes to educational policy (e.g. DfE, 2013a), which are most notably embodied in grammar tests for young children, which frame language in categorically 'correct' or 'incorrect' ways. This conceptualization of language comes to be reproduced in teacher discourse and classroom practice as a form of pedagogical coercion, with SE often being 'defended' on the grounds that it serves as a proxy for other social factors such as educational opportunities and employment prospects. I argue that linguicism and prescriptivism can have long-lasting and damaging effects on students' linguistic identities and attitudes towards language - both within the school and the wider community - and that pedagogical coercion can serve to further deprofessionalize teachers (see also Ball, 2003; Lingard, 2012; Shohamy, 2006).

Previous work on language policies in schools has tended to overlook issues of teacher knowledge and education in linguistics, which is typically limited, mostly due to a low number of linguistics graduates entering the profession, and a general lack of sociolinguistic content on teacher education programmes (see Giovanelli, 2016). Given that many teachers tend to conceptualize grammar as a system of strict, fixed 'rules' (Cushing, 2019), it is perhaps no surprise that linguicism emerges in classrooms and teacher discourse. My criticism in this paper has been not towards teachers, but towards systemic, governmental misconceptions of what language is, how and if it should be assessed, and the apparent denial of research evidence which strongly questions the nature of clause-level, decontextualized, error-correction language pedagogies. In the UK, there is a real need for more critical literature and language pedagogies as available resources, materials and training courses for teachers. In the US, these types of support networks for teachers have been shown to be invaluable in building teachers' critical language awareness, adopting sensible classroom practices and ways of thinking about what language is and how it works (e.g. Gebhard and Graham, 2018; Godley and Reaser, 2018; Metz, 2017).

Macro-level language policies are powerful mechanisms through which micro-level policy arbiters can be controlled, regulated and suppressed. I end this paper with a call-to-action for critical linguists and educators who value social justice and seek to challenge normative assumptions around language, education, community and society, and to challenge the powerful mechanisms which can intimidate teachers into certain ways of thinking and talking. This paper has demonstrated that for many teachers, these feelings of linguistic and pedagogical coercion are very real experiences, impacting upon the way that language is conceptualized and taught about in the classroom. A useful avenue for future research then, would be in the generating of data from classrooms in order to see how linguicism and prescriptive language policies play out in teacher-student interaction. Applied linguists are well-placed to do this, but must ensure that work is collaborative and sensitive to the contexts in which language policies and pedagogies are played out, in order to foster a community of critically engaged and linguistically astute practitioners, who are able to resist and challenge linguicism in all its forms.

\section{References}


Ball, S. (2003), "The teacher's soul and the terrors of performativity", Journal of Education Policy, Vol. 18 No 2, pp. 215-228.

Barakos, E. and Unger, J. (Eds.) (2016), Discursive Approaches to Language Policy. London, Palgrave.

Bourdieu, P. (1991), Language and Symbolic Power, Cambridge, Polity Press.

Bonacina-Pugh, F. (2012), "Researching 'practiced language policies': insights from conversation analysis", Language Policy, Vol. 11 No. 3, pp. 213-234.

Brinkmann, S. and Kvale, S. (2015), InterViews, London, Sage.

Cameron, D. (1995), Verbal Hygiene, London, Routledge.

Carter, R. (1996), "Politics and knowledge about language: the LINC project", in Hasan, R. and Williams, G (Eds.), Literacy in Society, Harlow, Longman, pp. 1-8.

Cheshire, J. (1982), "Dialect features and linguistic conflict in schools", Educational Review, Vol. 34 No.1, pp. 53-67.

Cheshire, J. \& Edwards, V. (1991). "School children as sociolinguistic researchers", Linguistics and Education Vol. 3 No. 3, pp. 225-250

Clark, U. (2001), War Words: Language, History and the Disciplining of English, Oxford, Elsevier.

Corson, D. (1999), Language Policy in Schools: A Resource for Teachers and Administrators, London, Lawrence Erlbaum.

Crowley, T. (2003), Standard English and the Politics of Language, Basingstoke: Palgrave Macmillan.

Cushing, I. (2018), “Grammar policy and pedagogy from primary to secondary school”, Literacy Vol. 53 No. 3, pp. 170-179.

Cushing, I. (2019), "Resources not rulebooks: metaphors for grammar in teachers' metalinguistic discourse", Metaphor and the Social World Vol. 9 No. 2, pp. 155-176.

Cushing, I. (in press), “The policy and policing of language in schools", Language in Society.

Dearden, L. and Vignoles, A. (2011), "Schools, markets and league tables", Fiscal Studies, Vol. 32 No.2, pp. 179-186.

Department for Education. (2011), "Independent review of key stage 2 testing, assessment and accountability", London, DfE.

Department for Education (2013a), "The national curriculum in England: key stages 1 and 2 framework document", London, DfE.

DfE. (2013b), “Teachers' standards”, London, DfE.

Duchêne, A. and Heller, M (Eds.) (2012), Language in Late Capitalism: Pride and Profit, London, Routledge. 
Elliot, V. (2018), "Thinking about the coding process in qualitative data analysis", The Qualitative Report, Vol. 23 No. 11, pp. 2850-2861.

Fairclough, N. (2014), Language and Power, London, Routledge.

Garvis, S. (2015), Narrative Constellations: Exploring Lived Experience in Education, Rotterdam, Sense Publishers.

Gebhard, M. and Graham, H. (2018), "Bats and grammar: developing critical language awareness in the context of school reform", English Teaching: Practice \& Critique, Vol. 17 No.3, pp. 281-297.

Gibb, N. (2016), The importance of the curriculum. Speech delivered at the Association of School and College Leaders, London, 27 April.

Gibb, N. (2018), Our reforms to primary education are beginning to work. Here's the evidence. Available at: <https://www.conservativehome.com/platform/2018/11/nick-gibb-our-reforms toprimary-education-are-beginning-to-work-heres-the-evidence.html>.

Giovanelli, M. (2016), “Developing beginning teachers' linguistic awareness: issues and practice in ITE", in Giovanelli, M. and Clayton, D. (Eds.), Knowing About Language: Linguistics and the Secondary English Classroom, London, Routledge, pp. 186-197.

Godley, A.J and Reaser, J. (2018), Critical Language Pedagogy: Interrogating Language, Dialects and Power in Teacher Education, New York, Peter Lang.

Godley, A.J., Carpenter, B.D. and Werner, C.A. (2007), “'I'll speak in proper slang': language ideologies in a daily editing activity", Reading Research Quarterly, Vol. 42 No. 1, pp. 100-133.

Gove, M. (2013). Michael Gove speaks about the importance of teaching. London: DfE.

Gove, M. (2014). An education system which works for every child. London: DfE.

Holborow, M. (2015), Language and Neoliberalism, London, Routledge.

Hudson, R. (2001), "Grammar-teaching and writing skills: the research evidence", Syntax in the Schools, Vol. 17, pp. 1-6.

Hudson, R. (2016), "The impact of policy on language teaching in UK schools", in Giovanelli, M. and Clayton, D. (Eds.), Knowing About Language: Linguistics and the Secondary English Classroom, London, Routledge, pp. 25-25.

Johnson, D. (2018), "Research methods in language policy and planning", in Tollefson, J. and Pérez-Milans, M. (Eds.), The Oxford Handbook of Language Policy and Planning, Oxford: Oxford University Press, pp. 51-70.

Levey, S. (2012). Understanding children's non-standard spoken English: a perspective from variationist sociolinguistics. Language and Education 26(5): 405-421.

Lingard, B. (2012), "Policy borrowing, policy learning: testing times in Australian schooling", Critical Studies in Education, Vol. 51 No. 2, pp. 129-147. 
May, S. (2012), Language and Minority Rights: Ethnicity, Nationalism and the Politics of Language, London: Routledge.

Metz, M. (2017), “Addressing English teachers' concerns about decentering Standard English”, English Teaching: Practice \& Critique, Vol. 16 No. 3, pp. 363-374.

Milroy, L. (1999), "Standard English and language ideology in Britain and the United States", in Bex, T. and Watts, R. (Eds.), Standard English: The Widening Debate, London, Routledge, 173206.

Myhill, D. and Watson, A. (2014), "The role of grammar in the writing curriculum: a review of the literature", Child Language Teaching and Therapy, Vol. 30 No. 1, pp. 41-62.

Park, J.S. and Wee, L. (2012), Markets of English: Linguistic Capital and Language Policy in a Globalizing World, London, Routledge.

Pennycook, A. (2001), Critical Applied Linguistics, London, Routledge.

Piller, I. (2016), Language and Social Justice, Oxford, Oxford University Press.

Ricento, T. and Hornberger, N. (1996), "Unpeeling the onion: language planning and policy and the ELT professional”, TESOL Quarterly, Vol. 30 No. 3, pp. 401-427.

Skutnabb-Kangas, T. (1988), "Multilingualism and the education of minority children", in Skutnabb-Kangas, T. and Cummins, J. (Eds.), Minority Education: from Shame to Struggle, Clevedon, Multilingual Matters, pp. 9-44.

Shohamy, E. (2001), The power of tests: A Critical Perspective on the Uses of Language Tests. Singapore: Longman.

Shohamy, E. (2006), Language Policy: Hidden Agendas and New Approaches. London, Routledge.

Snell, J. (2018), "Solidarity, stance and class identities”, Language in Society, Vol. 47 No. 5, pp. 665691.

Tollefson, J. (1991), Planning Language, Planning Inequality: Language Policy in the Community. London, Longman.

Yandell, J. and Brady, M. (2016), "English and the politics of knowledge", English in Education, Vol. 50 No. 1 , pp. 44-59. 